\title{
PRODUKTIVITAS RUMPON PORTABLE MENGGUNAKAN PANCING ULUR DI PERAIRAN JEPARA
}

\section{PRODUCTIVITY OF HANDLINE WITH PORTABLE FISH AGGREGATING DEVICES (FADS) IN JEPARA WATERS}

\author{
Roza Yusfiandayani ${ }^{2}$, Desi Rezki Amelia ${ }^{1}$, Mochammad Riyanto ${ }^{2}$ \\ ${ }^{1}$ Program studi Pemanfaatan Sumberdaya Perikanan, \\ ${ }^{2}$ Departemen Pemanfataan Sumberdaya Perikanan, \\ Fakultas Perikanan dan Ilmu Kelautan, Institut Pertanian Bogor \\ Korespondensi: ochaipb@gmail.com, hascaryo@yahoo.com
}

\begin{abstract}
The portable Fish Aggregating Devices (FADs) is an auxiliary fishing gear that can be operated on a multiple-time basis, as a fish-collecting device with an attractor. The purposes of the study are to determine the catch composition, length and weight frequency of the catch around portable FADs, determine the catch productivity of handlinearound FADs at the day and night time. The catch composition were consist of: kawakawa (Eutbynnus affinis), short mackerel (Rastrelliger branchysoma), swordfish (Xiphias gladius), great barracuda (Sphyraena barracuda), and redbelly yellowtail fusilier (Caesio cuning). Total catch by handline was 160 individual. The length and weight relationship for dominant fish species was $\mathrm{b}<3$ for Euthynnus affinis and Rastrelliger branchysoma (allometric negative) while $\mathrm{b}>3$ for Xiphias gladius (allometric positive). The Mann Whitney U test shows that there was not significant different catch between day and night time operating hours.
\end{abstract}

Keyword: FADs, Jepara, portable, productivity

\section{ABSTRAK}

Rumpon portable adalah alat bantu penangkapan yang dapat dioperasikan secara multi-waktu, sebagai alat pengumpulan ikan. Tujuan penelitian ini adalah untuk menjelaskan komposisi tangkapan, panjang dan frekuensi tangkapan tangkapan di sekitar portable rumpon, menentukan produktivitas tangkapan handliner pada siang dan malam hari. Komposisi tangkapan terdiri dari tongkol (Euthynnus affinis), kembung (Rastrelliger branchysoma), ikan todak (Xiphias gladius), barakuda (Sphyraena barakuda), dan ikan ekor kuning (Caesio cuning). Total tangkapan dengan handline adalah 160 ekor. Hubungan panjang dan berat untuk jenis ikan dominan adalah $\mathrm{b}<3$ untuk ikan tongkol dan ikan kembung (allometric negative) sedangkan b> 3 untuk ikan todak. Uji Mann Whitney U menunjukkan bahwa tidak ada perbedaan yang signifikan antara jam operasi siang dan malam hari.

Kata kunci: rumpon, Jepara, portable, produktivitas 


\section{PENDAHULUAN}

\section{Latar belakang}

Jepara merupakan salah satu kabupaten di Jawa Tengah yang terletak di Pantura Timur dengan garis pantai sepanjang $72 \mathrm{~km}$. Salah satu alat tangkap yang beroperasi di Jepara yaitu pancing ulur. Alat tangkap pancing ulur merupakan alat tangkap tradisional yang sebagian besar digunakan oleh nelayan Jepara. Komponen dari alat tangkap pancing ulur meliputi gulungan tali, tali pancing, pemberat dan mata pancing (Barus 1989). Jenis hasil tangkapannya yaitu ikan pelagis besar dan pelagis kecil diantaranya tenggiri (Scomberomorus sp.), tongkol (Euthinnus sp.), madidihang (Thunnus albacares) dan tuna mata besar (Thunnus obesus) (kkji. kp3k.kkp.go.id). Potensi perikanan tangkap laut yang tersebar di perairan Jawa Tengah sekitar 1.873 .530 ton/tahun meliputi Laut Jawa sekitar 796.640 ton/tahun dan Samudera Indonesia sekitar 1.076.890 ton/ tahun (DKP Jepara 2016).

Ikan pelagis besar dan ikan pelagis kecil dapat ditangkap dengan menggunakan alat bantu penangkapan ikan yaitu rumpon. Menurut kepmen KP PER.71/MEN/2016 pasal 19, rumpon adalah alat bantu untuk mengumpulkan ikan dengan menggunakan berbagai bentuk dan jenis atraktor dari benda padat yang berfungsi untuk memikat ikan agar berkumpul. Ketentuan mengenai rumpon diatur dalam peraturan menteri tersendiri dalam pasal 31 yang menyebutkan bahwa Alat Penangkap Ikan (API) pancing ulur bersifat pasif dengan alat bantu menggunakan rumpon, kapal tanpa motor dan semua ukuran kapal penangkap ikan dan di semua jalur penangkapan ikan di WPPNRI.

Rumpon yang biasa digunakan nelayan adalah rumpon konvensional yang menetap di perairan. Rumpon menetap membutuhkan biaya yang mahal dalam produksinya dan kadangkala hilang karena dicuri oleh nelayan lain. Mengantisipasi hal tersebut maka dibuat inovasi rumpon portable. Penelitian ini menggunakan alat bantu penangkapan berupa rumpon, yaitu rumpon portable berbahan fiber. Pengoperasian rumpon portable tidak dilakukan secara menetap melainkan dapat berpindah lokasi sesuai dengan daerah penangkapan yang diinginkan serta dapat dibawa dan dipindahkan ke daerah lain atau disimpan hingga dilakukan operasi penangkapan ikan selanjutnya (Yusfiandayani et al. 2013).

Pengkajian mengenai produktivitas pancing ulur menggunakan rumpon portable berbahan fiber di Jepara belum pernah dilakukan.

\section{METODE PENELITIAN}

Penelitian berlangsung selama 5 bulan yaitu dari bulan Februari-Juni 2016. Penelitian ini menggunakan metode experimental fishing atau uji coba rumpon portable berbahan fiber di perairan Jepara, Jawa Tengah.

Bahan yang digunakan dalam penelitian ini yaitu: Satu unit rumpon portable berbahan fiber yang didesain oleh tim pengkajian rumpon IPB (Yusfiandayani et al. 2016) dengan ukuran panjang 62.5 $\mathrm{cm}$, lebar $20 \mathrm{~cm}$, dan tinggi $48 \mathrm{~cm}$ sebagai rangka rumpon, tali $\mathrm{PE}$ sebagai tali utama, tali rafia warna biru sebagai atraktor, electric fish atractor menggunakan frekuensi suara dengan frekuensi sebesar 1.000-5.000 Hz, 6.000-10.000 Hz, 11.000-15.000 Hz dan 3 unit pancing ulur yang memiliki 10 branch line dan dilengkapi dengan pemberat yang memiliki berat yaitu $2 \mathrm{~kg}$, panjang main line yaitu $25 \mathrm{~m}$, panjang branch line yaitu $35 \mathrm{~cm}$.

Alat yang digunakan dalam penelitian ini meliputi: GPS (Global Positioning System) untuk mengetahui posisi operasi penangkapan ikan, measuring board dan meteran untuk mengukur panjang ikan, timbangan digital untuk menghitung berat material rumpon dan berat ikan, alat tulis dan kertas newtop yang digunakan untuk mencatat data dan informasi, tali PE yang digunakan untuk mengikat rumpon ke kapal, 3 unit pancing ulur masing-masing berukuran 35, 40 dan 45 dan memiliki 10 branch line, kapal motor berukuran 5 GT.

\section{Prosedur penelitian}

Metode penelitian yang digunakan adalah metode experimental fishing yang merupakan uji coba langsung terhadap rumpon portable sebagai alat pengumpul ikan. Pengambilan data dilakukan dari tanggal 29 Mei - 4 Juni 2016. Proses operasi penangkapan dilakukan sebanyak enam kali ulangan dengan tiga jam pengoperasian rumpon per ulangan dalam satu hari. Penangkapan ikan dimulai pukul 05.00 WIB. Tahap-tahap operasi penangkapan yaitu:

1. Tahap persiapan. Pengecekan terhadap kapal (kondisi mesin, kondisi box dan 
kondisi tempat penyimpanan hasil tangkapan), alat tangkap (pancing ulur) beserta umpan dan rumpon portable serta perbekalan selama melaut.

2. Fishing base ke fishing ground (pemberangkatan dilakukan pada malam hari).

3. Tahap pengoperasian rumpon. Rumpon diturunkan ke laut pada pukul 04.00 WIB (EFA, tali utama dan atraktor serta rangka rumpon sebagai pelampung), satu jam setelah diturunkan, dimulai operasi penangkapan menggunakan 3 unit pancing ulur dengan umpan berupa cumi yang telah dipotong-potong, pancing ulur yang digunakan memiliki panjang $25 \mathrm{~m}$ dengan 10 branch line, pemancingan berjarak $3 \mathrm{~m}$, panjang tali atraktor 9 $\mathrm{m}$ dan kedalaman perairan yaitu $50 \mathrm{~m}$, rumpon diangkat ke kapal setelah 3 jam. Satu jam kemudian rumpon kembali diturunkan, demikian seterusnya sehingga dalam 1 hari dilakukan 6 kali pengoperasian. Pemancingan dilakukan oleh nelayan dan juga peneliti.

4. Pengambilan data. Data primer dikumpulkan dengan melakukan penangkapan ikan sebanyak 6 kali ulangan dalam 1 hari. Data yang dikumpulkan meliputi komposisi jenis ikan dan pengukuran panjang $(\mathrm{cm})$ serta berat ikan $(\mathrm{kg})$ yang tertangkap kemudian dianalisis berdasarkan waktu operasi.

\section{Prosedur analisis data}

Analisis data dilakukan secara deskriptif terhadap komposisi hasil tangkapan, ukuran panjang yang digunakan adalah ukuran panjang total, dan untuk ukuran berat digunakan berat total.

\section{Pengaruh waktu terhadap hasil tangkapan}

Data pada penelitian ini dianalisis untuk mengetahui pengaruh waktu terhadap produktivitas. Uji yang digunakan untuk menganalisis pengaruh umumnya menggunakan ANOVA. Analisis ANOVA digunakan jika populasi sampel bersifat normal. Namun jika data menyebar secara tidak normal, maka dilakukan analisis data non parametrik dengan menggunakan uji Mann Witney yang bertujuan untuk membandingkan dua kelompok yang memiliki ukuran sampel yang berbeda (Sarwono \& Budiono 2014). Dua kelompok yang dibandingkan yaitu waktu siang dan waktu malam. Pengujian kenormalan data populasi menggunakan uji Kolmogorovsmirnov pada software SPSS 22. Hipotesis uji Mann Whitney adalah sebagai berikut: HO : Waktu pengoperasian siang dan malam tidak berpengaruh nyata terhadap produktivitas hasil tangkapan.

$\mathrm{H} 1$ : Waktu pengoperasian siang dan malam berpengaruh nyata terhadap produktivitas hasil tangkapan.

Hipotesis yang digunakan dalam pengambilan keputusan yaitu :

Sig. (2-tailed $)<$ taraf nyata (a) maka Ho tidak diterima

Sig. (2-tailed) > taraf nyata (a) maka Ho diterima

dimana; $a=0.05 \quad(5 \%)$ dengan tingkat keyakinan 95\%

\section{Analisis produktivitas hasil tangkapan siang dan malam}

Perhitungan produktivitas bertujuan untuk melihat kemampuan alat tangkap untuk berproduksi berdasarkan waktu tertentu. Produktivitas menurut (Nelwan et al. 2010) dihitung menggunakan rumus:

$$
\text { Produktivitas }=\frac{c}{f}
$$

\section{Hubungan panjang berat hasil tangkapan}

Berat dianggap sebagai suatu fungsi dari panjang. Menurut Effendie (1997) untuk menganalisis hubungan panjang berat digunakan rumus :

$$
W=\alpha L^{\beta}
$$

Uji t dilakukan terhadap nilai b untuk mengetahui apakah nilai $\mathrm{b}=3$ (isometrik) atau $b \neq 3$ (alometrik). Alometrik positif, jika $b>3$ (pertambahan berat lebih cepat dari pertambahan panjang) dan allometrik negatif, jika $\mathrm{b}<3$ (pertambahan panjang lebih cepat daripada pertambahan berat).

$$
\text { Thit }=\left|\frac{b 1-b 0}{S b i}\right|
$$

Selang kepercayaan 95\%, bandingkan nilai Thit dengan Ttab dengan asumsi :

Thit $>$ Ttab : Tolak HO

Thit $<$ Ttab : Terima HO 


\section{HASIL DAN PEMBAHASAN}

\section{Hasil tangkapan rumpon portable}

Jumlah hasil tangkapan selama enam hari penelitian dibagi dalam lima jenis diantaranya tongkol, kembung, todak, barakuda dan selar kuning dengan total hasil tangkapan berjumlah 160 ekor (Gambar 1).

Komposisi jumlah hasil tangkapan perhari yaitu pada hari pertama total ikan yang tertangkap sebanyak 24 ekor, hari ke-2 sebanyak 33 ekor, hari ke-3 sebanyak 29 ekor, hari ke-4 sebanyak 28 ekor, hari ke-5 sebanyak 21 ekor dan hari ke-6 sebanyak 25 ekor. Hasil tangkapan perhari mengalami fluktuatif dengan total hasil tangkapan terbanyak terjadi pada hari ke-2 (Gambar 2).

Total berat hasil tangkapan yang diperoleh selama penelitian yaitu sebesar $45.76 \mathrm{~kg}$. Hasil tangkapan ikan dapat dilihat pada hari pertama sebesar $8.63 \mathrm{~kg}$ atau $18.86 \%$. Berat hasil tangkapan pada hari ke-2 sebesar $7.67 \mathrm{~kg}$ atau $16.76 \%$, berat hasil tangkapan hari ke-3 sebesar $8.39 \mathrm{~kg}$ atau $18.3 \%$, berat hasil tangkapan hari ke-4 yaitu $8.74 \mathrm{~kg}$ atau $19.1 \%$, serta hasil tangkapan yang paling ringan tertangkap yaitu pada hari $\mathrm{ke}-5$ sebesar $5.94 \mathrm{~kg}$ atau
$13 \%$ serta hasil tangkapan ke-6 yaitu 6.39. Hasil tangkapan yang didapatkan selama enam hari penelitian yaitu sebesar $45.76 \mathrm{~kg}$ (Gambar 3).

\section{Produktivitas hasil tangkapan siang dan malam}

Produktivitas penangkapan menggunakan pancing ulur dengan alat bantu rumpon portable merupakan jumlah hasil tangkapan yang dapat dihasilkan oleh pancing ulur menggunakan rumpon portable oleh setiap kali pengoperasiannya. Produktivitas yang dihitung pada penelitian ini menggunakan waktu yaitu per 3 jam sekali bukan menggunakan trip karena alat tangkap yang dioperasikan hanya selama 6 hari (1 trip). Produksi hasil tangkapan dibedakan menjadi dua periode yaitu siang dan malam.

Produktivitas pada siang hari sebesar $4.40 \mathrm{~kg} / 3$ jam dan pada malam hari sebesar $3.23 \mathrm{~kg} / 3$ jam. Uji Mann Whitney menunjukkan bahwa nilai signifikansi yang diperoleh sebesar 0.513 artinya besar dari nilai a $(0.513 \geq 0.05)$. Dapat disimpulkan bahwa perbedaan waktu siang dan malam tidak memiliki pengaruh yang signifikan terhadap hasil tangkapan (Tabel 1).

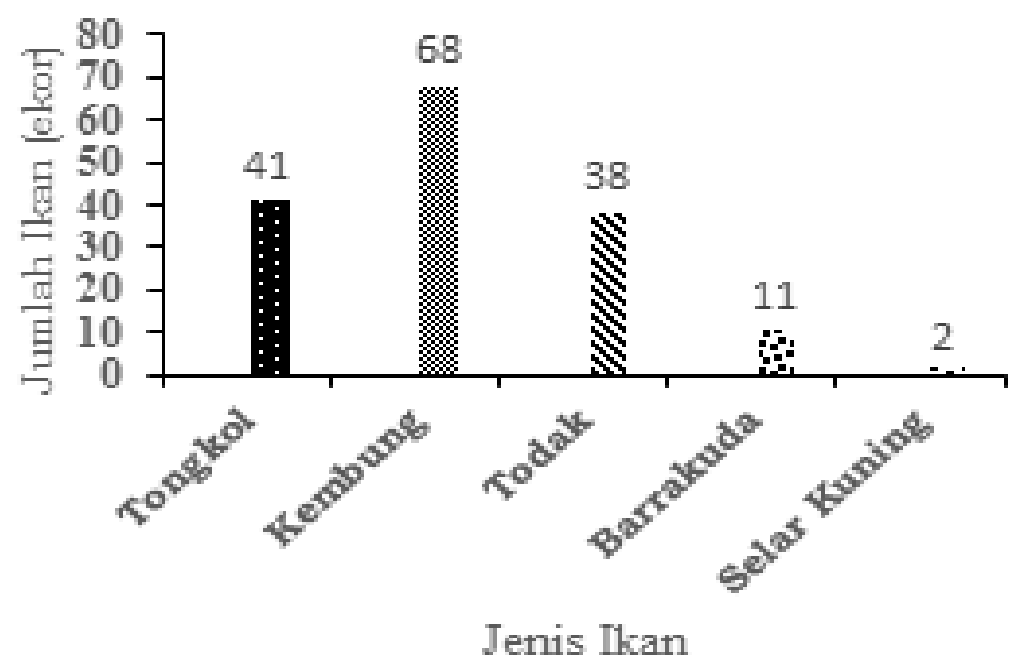

Gambar 1. Jumlah hasil tangkapan per jenis 


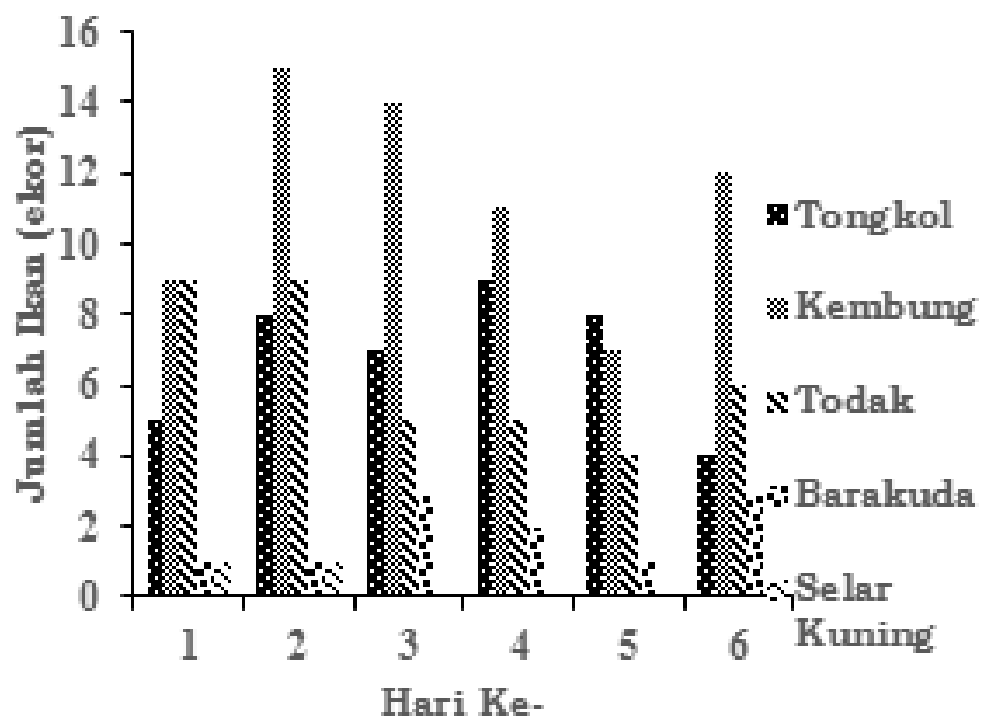

Gambar 2. Komposisi jenis ikan yang tertangkap per hari operasi

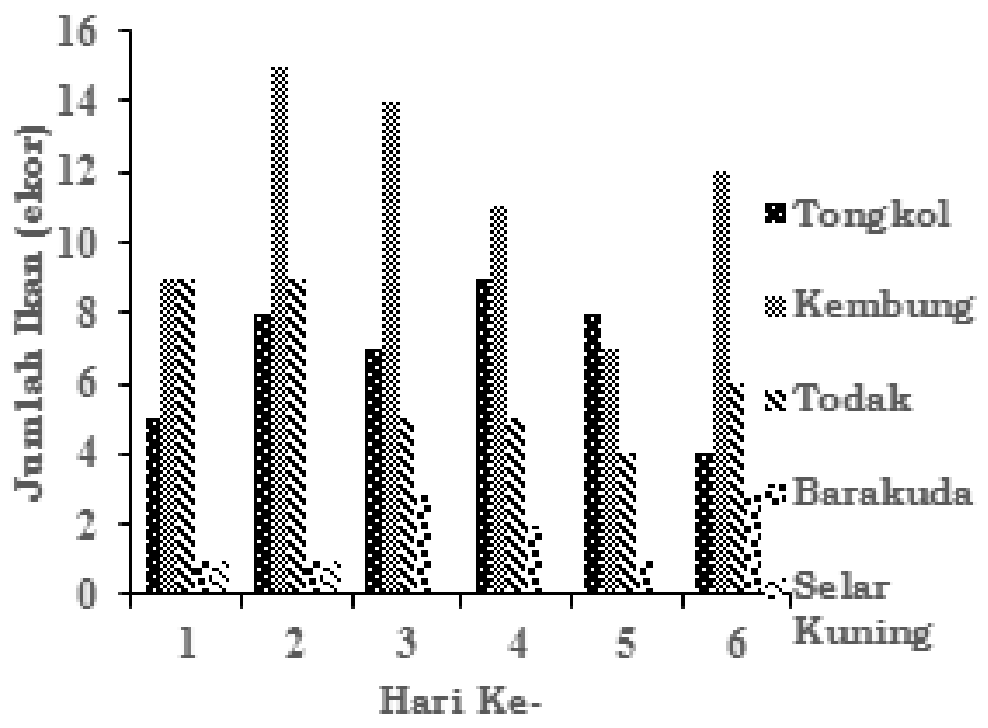

Gambar 3. Hasil tangkapan per berat hasil tangkapan

Tabel 1. Produktivitas menggunakan rumpon portable pada siang dan malam

\begin{tabular}{lccc}
\hline Waktu & Ulangan ke- & Berat (kg) & Produktivitas (kg/3 jam) \\
\hline Siang & 1 & 9.07 & 1.51 \\
& 2 & 8.78 & 1.46 \\
Jumlah & 3 & 8.58 & 1.43 \\
\hline Malam & & & $\mathbf{4 . 4 0}$ \\
& 4 & 8.44 & 1.41 \\
Jumlah & 5 & 5.38 & 0.90 \\
& 6 & 5.51 & 0.92 \\
\hline
\end{tabular}




\section{Hubungan panjang dan berat ikan}

\section{Tongkol}

Hasil analisis menunjukkan bahwa nilai a pada tongkol sebesar 0.0146 dan nilai b sebesar 2. 955 dengan koefisien determinasi (R2) sebesar 0.8604 atau $86 \%$ dan korelasi sebesar 0.93 yang tergolong korelasi sangat kuat sehingga model regresinya adalah $\mathrm{W}=0.0146 \mathrm{~L} 2.955$

Hal ini bermakna bahwa model regresi mampu menjelaskan hubungan panjang berat tongkol sebesar 86\%. Nilai $\mathrm{b}<3$ menunjukkan bahwa pola pertumbuhan ikan tongkol adalah alometrik negatif artinya pertambahan panjang lebih cepat dibandingkan pertambahan berat.

Uji $\mathrm{T}$ yang dilakukan dengan tingkat kepercayaan 95\%, didapatkan Thit> Ttab (tolak HO) yang artinya peningkatan pertambahan berat tidak sebanding dengan pertumbuhan panjang.

\section{Todak}

Model regresi ikan todak yaitu $\mathrm{W}=$ 0.0012L3.2658 dengan nilai R2 sebesar
0.9463 atau 94\% dengan nilai korelasi sebesar 0.97 yang tergolong korelasi sangat kuat. Hal ini menjelaskan bahwa model regresi mampu menjelaskan hubungan panjang berat ikan todak sebesar 94\%.

Nilai $b>3$ menunjukkan bahwa pertambahan berat lebih cepat dibandingkan pertambahan panjang (alometrik positif). Berdasarkan nilai $b$, dapat dilihat bahwa Thit< Ttab (Terima HO) yang artinya peningkatan pertambahan berat sebanding dengan pertumbuhan panjang.

\section{Kembung}

Model regresi hubungan panjang berat ikan kembung yaitu $\mathrm{W}=0.0189 \mathrm{~L} 2,9002$ dengan nilai determinasi (R2) sebesar 0.9228 atau $92 \%$ yang artinya bahwa model regresi mampu menjelaskan hubungan panjang berat ikan kembung sebesar $92 \%$ dengan nilai korelasi sebesar 0.96 yang tergolong korelasi sangat kuat. Nilai $\mathrm{b}<3$ menunjukkan pola pertumbuhan ikan kembung adalah alometrik negatif artinya pertambahan panjang lebih cepat dibandingkan pertambahan berat.

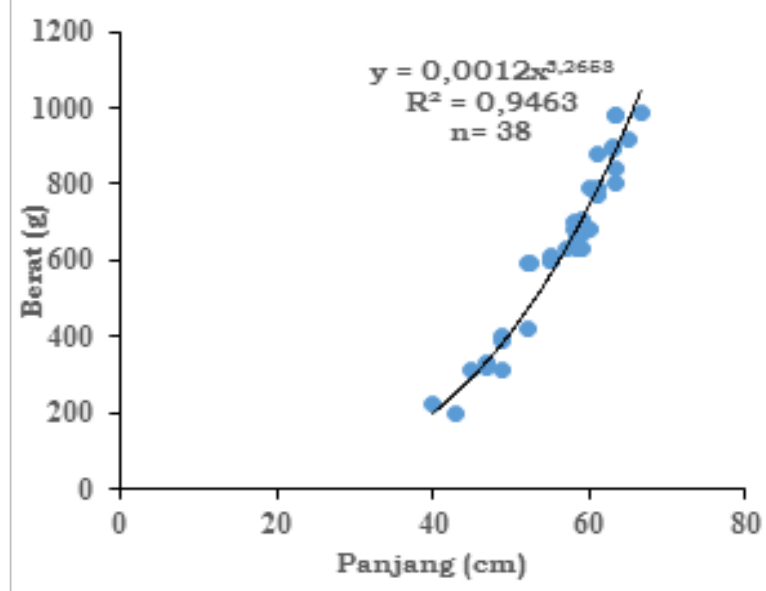

Gambar 4. Gambar hubungan panjang berat ikan tongkol

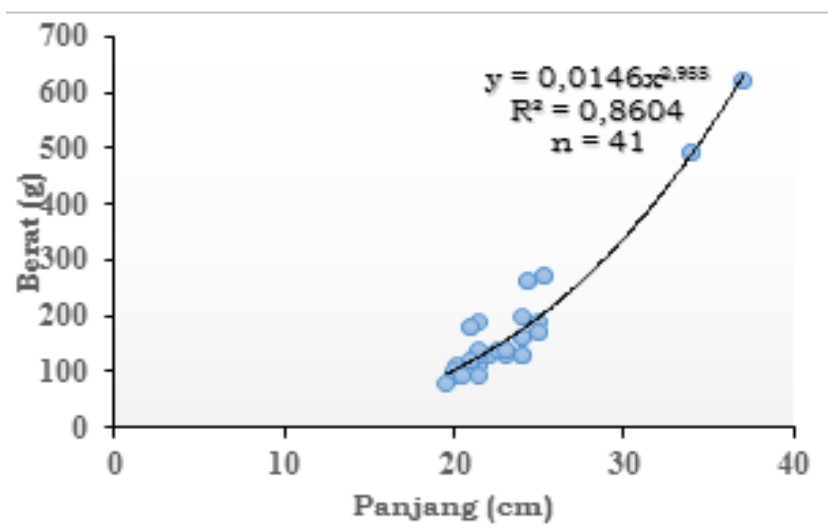

Gambar 5. Gambar hubungan panjang bobot ikan todak 


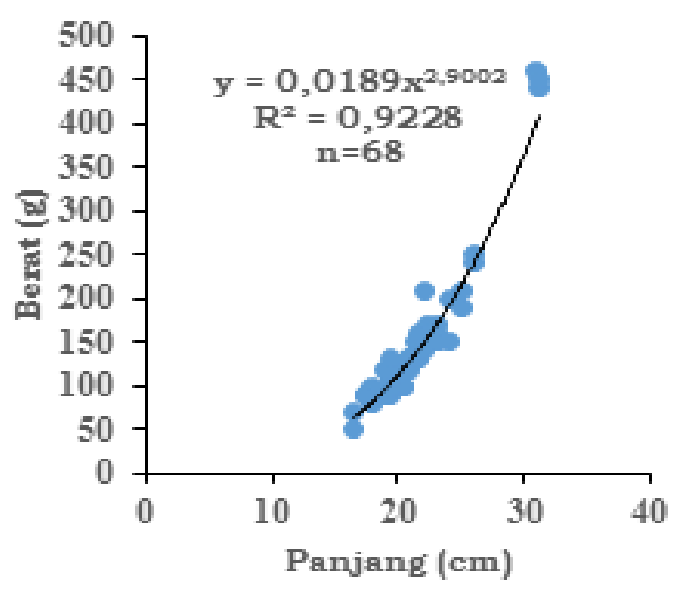

Gambar 6. Gambar hubungan panjang dan berat ikan kembung

Hasil uji T menunjukkan bahwa Thit< Ttab (Terima HO) artinya bahwa peningkatan pertambahan berat sebanding dengan pertumbuhan panjang. Moazzam et al. 2005 dalam Sinaga 2010 menyatakan Ikan kembung merupakan jenis ikan pelagis kecil bergerombol yang hidup di perairan dangkal. Hal ini sesuai dengan hasil penelitian yaitu komposisi hasil tangkapan disekitar rumpon selama penelitian cukup bervariasi namun didominasi oleh ikan kembung yang berjumlah 68 ekor.

Suhu perairan saat dilakukan pengoperasian berkisar antara 290300C. Ikan kembung (Euthynnus affinis) merupakan ikan pelagis kecil dengan pola penyebarannya di seluruh Indo-Barat dengan suhu $180-29{ }^{\circ} \mathrm{C}$ (Froese \& Pauly 2007). Menurut Sinaga (2010) bahwa pada musim barat yaitu bulan Juni sampai September ikan kembung yang ada di Laut Jawa bermigrasi dari Laut Cina Selatan dan Samudera Hindia melalui Selat Sunda. Migrasi ini terjadi karena arus laut yang disebabkan oleh perubahan angin musim barat dan timur.

Yusfiandayani et al. (2014) menyatakan bahwa berkumpulnya ikan di sekitar rumpon disebabkan oleh adanya pemikat/atraktor sebagai alat pengumpul ikan karena dapat mengkonsentrasikan ikan yang tertangkap pada alat tangkap pancing ulur. Produktivitas pancing ulur menggunakan rumpon portable pada siang hari lebih banyak dibandingkan malam hari. Hal ini dapat dilihat bahwa total produktivitas siang hari sebesar $4.4 \mathrm{~kg}$ sedangkan pada malam hari sebesar 3.23 kg hal ini diduga karena hasil tangkapan berkumpul di sekitar rumpon pada siang hari lebih banyak dibandingkan malam hari. Menurut Laevastu \& Hayes (1981) bahwa pada siang hari ikan pelagis cenderung bergerombol di permukaan sedangkan pada malam hari menyebar secara merata di kolom perairan. Rumpon portable berbahan fiber dioperasikan dalam 6 waktu operasional. Jumlah hasil tangkapan terbanyak terjadi pada pukul 09.00-12.00 yaitu sebanyak 36 ekor. Pada pukul 09.0012.00 perairan Jepara dapat dikatakan tenang dibandingkan pada saat malam hari sehingga pemancingan di sekitar rumpon portable berjalan cukup lancar.

Hasil uji Mann Whitney menunjukkan bahwa nilai signifikansi yang didapatkan lebih besar dari nilai a. Kesimpulan yang didapat yaitu perbedaan waktu siang dan malam tidak memiliki pengaruh yang signifikan terhadap hasil tangkapan. Namun, berdasarkan deskripsi hasil tangkapan disarankan penggunaan rumpon sebagai alat bantu penangkapan dioperasikan pada siang hari karena produksi hasil tangkapan lebih banyak pada siang hari.

Hasil uji $t$ terhadap nilai $b$ menunjukkan bahwa nilai panjang berat dari 3 jenis ikan adalah allometrik yaitu pertambahan berat tidak seimbang dengan pertambahan panjang. Hubungan panjang berat pada 2 jenis ikan menunjukkan pola pertumbuhan alometrik negatif yaitu cenderung memiliki berat yang lebih ringan karena makanan yang ada di dalam tubuhnya digunakan untuk melakukan pertumbuhan dan perkembangan. Sedangkan pola pertumbuhan alometrik positif terjadi pada ikan todak. Hal ini berbeda dengan hasil penelitian Chodrijah et al. (2013) di perairan Laut Jawa bahwa ikan tongkol komo memiliki pertumbuhan isometrik dengan nilai $\mathrm{b}=3.1267$. Panjang berat ikan kembung pada perairan Palabuhanratu bersifat allometrik positif dengan nilai b sebesar 3.24 (Nasution 2014). Perbedaan hubungan panjang dan 
berat ikan dipengaruhi beberapa faktor diantaranya habitat, lingkungan, musim, jenis makanan, matang gonad, kesehatan dan jenis kelamin (Hossain 2010).

\section{KESIMPULAN}

Kesimpulan yang dapat diambil dari penelitian ini yaitu: komposisi hasil tangkapan rumpon portable di Perairan Jepara berjumlah 160 ekor serta bersifat allometrik negatif pada ikan kembung dan tongkol namun bersifat allometrik positif pada ikan todak, produktivitas pancing ulur di sekitar rumpon portable pada siang hari lebih tinggi dari malam hari. Produktivitas pancing ulur menggunakan rumpon paling besar terjadi antara pada pukul 09.00-12.00.

\section{DAFTAR PUSTAKA}

Ariawan DW. 2015. Analisis hasil tangkapan pancing ulur (handline) pada rumpon portable di Perairan SelatanPalabuhanratu, Jawa Barat [skripsi]. Bogor (ID): Institut Pertanian Bogor

Aunuddin. 2005. Statistika: Rancangan dan Analisis Data. Bogor (ID): IPB Press.

Chodrijah U, Hidayat T, Noegroho T. 2013. Estimasi parameter populasi ikan tongkol komo (Euthynnus affinis) di Perairan Laut Jawa. Bawal. 5(3): 167174

Effendie MI. 1997. Biologi Perikanan. Yogyakarta (ID): Yayasan Pustaka Nusatama.

Fardhani I. 2015. Produktifitas rumpon portable di Perairan Palabuhanratu Sukabumi Jawa Barat [skripsi]. Bogor (ID): Institut Pertanian Bogor.

Froese R, Pauly DE. 2007. Fishbase, version 10/2007. www.fishbase.org

http://www.pipp.djpt.kkp.go.id [diakses September 2016]

http://www.kkji.kp3k.kkp.go.id. [diakses Agustus 2016]

http:/www./jeparakab.go.id [diakses Agustus 2016]

Jamal M. 2003. Studi penggunaan rumpon untuk meningkatkan produksi hasil tangkapan gillnet dan bubu dasar yang dioperasikan di Perairan Kabupaten Sinjai Sulawesi Selatan. Lutjanus. JTPK. 8 (2): 223-231

Karna. 1997. Studi tentang hasil tangkapan rawai tuna dengan menggunakan umpan cumi-cumi (Loligo spp.) [skripsi]. Bogor (ID): Institut Pertanian Bogor

Kunarso et al. 2016. Musim ikan di Perairan Laut Jawa Kabupaten Jepara dan prediksi lokasi fishing ground-nya. Prosiding Semnas tahunan ke-V.

Laevastu T, Hayes ML. 1981. Fisheries Oceanography and Ecology. Farnham (UK): Fishing New Books Ltd.

Moazzam M, Osmany HB, Zohra K. 2005. Some aspects of biology and fisheries: Indian mackerel (Rastrelliger kanagurta). Journal Marine Fisheries Department, Government of Pakistan, Fish Harbour. 16: 58-75

Monintja DR. 1990. Study on the development of rumpon as fish aggregating device (FADs). Bul FPIK IPB. 3(2): 137

Nelwan AFP, Sondita MFA, Monintja DR, Simbolon D. 2010. Evaluasi produksi perikanan tangkap pelagis kecil di Perairan Pantai Barat Sulawesi Selatan. Maritek. 10 (1): 41-51

PP Jateng Provinsi 2015. Diakses pada September 2016

Sarwono J, Budiono H. 2014. Riset Skripsi Tesis dan Disertasi dengan SPSS, AMOS dan Exel. Jakarta (ID): Elexmedia Komputindo

Sinaga P. 2010. Dinamika stok dan analisis bio-ekonomi ikan kembung lelaki (Rastrelliger kanagurta) di TPI BlanakanSubang, Jawa Barat [skripsi]. Bogor (ID): Institut Pertanian Bogor

Soekartawi. 2003. Teori Ekonomi Produksi. Jakarta (ID): PT. Raja Grafindo Persada.

Subani W. 1986. Telaah penggunaan rumpon dan payaos dalam Perikanan Indonesia. Jurnal Penelitian Perikanan Laut, BPPL Jakarta. 35: 35-45

Sugiyono. 2007. Metode Penelitian Pendidikan Pendekatan Kuantitatif, Kualitatif, dan $R \& D$. Bandung (ID): ALFABETA

Sulandari A. 2011. Strategi Peningkatan Produksi Pada Nelayan Pancing Tonda Di Perairan Teluk Prigi (PPN Prigi) [tesis]. Depok (ID): Universitas Indonesia

Yusfiandayani R, Jaya I, Baskoro MS. 2013. Uji coba penangkapan pada rumpon portable di Perairan Palabuhanratu. JTPK. 4 (1): 89-98

Yusfiandayani R, Jaya I, Baskoro MS. 2014. Konstruksi dan produktivitas rumpon portable Tuna di Perairan Palabuhanratu. JTPK. 5 (2): 117-127. 